\title{
Exploring University Teachers' Understanding of Learner Autonomy
}

\author{
Saleh S. Al-Busaidi \\ Curriculum and Instruction, Sultan Qaboos University, Muscat, Sultanate of Oman \\ Faisal S. Al-Maamari \\ Language Centre, Sultan Qaboos University, Muscat, Sultanate of Oman
}

\begin{abstract}
Learner autonomy (LA) has received a lot of attention in ELT research. This paper explores learner autonomy in theory and practice from the teachers' points of view. The authors first review the literature on learner autonomy and explore the relationship between learner autonomy and teachers' beliefs. After that, they report on a qualitative study that set to examine teachers' perspectives on learner autonomy. The study aimed at investigating the teachers' views with regards to their definition of learner autonomy and the sources of their ideas. Based on the findings of the study, the teachers defined LA from different perspectives, reflecting their diverse experiences and perceptions about the concept. Some of the definitions are influenced by the teachers' classroom experience while others are based on the literature. The teachers also varied in the sources of their definitions, ranging from pre- or in-service teacher training to classroom practices. This study brings new insights to the literature on LA where it sheds light into teachers' definitions of LA and the sources of these definitions, an area that has not been explored much in the literature.
\end{abstract}

Index Terms-learner autonomy, definition of learner autonomy, teacher beliefs, curriculum, teaching methodology

\section{INTRODUCTION}

Learner autonomy has received broad international attention both amongst scholars and practitioners. It is seen as a way to empower students and make them responsible for their own learning. Since Holec's pioneering work of 1981, there have been many attempts to define the term and determine what it entails. Definitions differ depending on the writer and the context where the term is used. LA is generally defined as the ability to take charge of one's own learning. The emergence of this concept has been part of a wide range of ideas in education that have promoted more learner centered instruction, where learners are given more choices and are allowed to make their own decisions. In spite of the abundance of theoretical definitions from various scholars, little attention has been paid to exploring the teachers' perspective.

Much of the research on LA has focused on the learners. Researchers have tried to identify the traits that characterize autonomous learners (see for example, Little, 1990). We would like to argue that it is equally important to explore the teacher dimension of LA, given the impact teachers' beliefs can have on the learning process. The extent of teachers' support for LA is based on their own learning and understanding. As Edelhoff (1984, p. 189) cited in Dam (2008, p. 26), has put it: ...teachers will hardly be prepared or able to administer autonomous learning processes in their students if their own learning is not geared to the same principles". Understanding teachers' beliefs is crucial in the development of LA and in the effective integration of LA in teaching. Research on teacher beliefs shows that the beliefs that teachers hold about certain educational concepts, approaches and methodologies influence their practices (see for example, Clark and Peterson (1986); Isenberg (1990); Hedge and Cassidy (2009)). Teachers do not simply hold to a consistent set of beliefs about LA underpinned by a single coherent conception of language learning. There is a host of personal and professional factors that shape teachers' conceptions. It is therefore important to shed light into these conceptions and the underlying principles. Such research will help promote reflection and constructive dialogue among teachers about the principles surrounding this concept.

This study brings new insights to the literature on LA. There are many studies that have looked into teachers' views on LA with regards to students' abilities and what they can and cannot do. There are also many studies that have investigated the factors that support or hinder the development of LA in a certain educational setting. However, there is not much research; in fact, we could not find any that investigates teachers' definitions of LA and even less on the sources of these definitions. Previous research has referred to the classic definitions of LA in interpreting teachers' views and practices. Therefore, we believe that our paper will bring new insights into research on LA. Understanding what LA means to teachers and the principles that underpin their views is crucial for an effective integration of LA into the language curriculum. Such research will also help bridge the gap between the theoretical definition of LA and the teachers' understanding of the concept. 
In the following sections, the concept of learner autonomy and the relationship between teachers' beliefs and learner autonomy are presented. This is followed by the description of the study, the data analysis, the findings, the discussion and the conclusion.

\section{LITERATURE REVIEW}

\section{A. Learner Autonomy}

Learner autonomy has been a key concept in education for over 30 years. Holec's (1981, p. 3) pioneering work and his classic definition of learner autonomy as "the ability to take charge of one's own learning... to have, and to hold, the responsibility for all the decisions concerning all aspects of this learning" is still widely cited. According to Holec, learners are able to manage different aspects of their learning, such as determining the objectives, defining the content, selecting methods and techniques to be used, monitoring the procedure of acquisition and evaluating what has been acquired.

Following Holec's classic definition, many terms have been used to define the nature of this responsibility. Terms such as 'ability' (Benson, 2006), 'capacity' (Little, 1991), 'take responsibility', and 'take control' have been used. The term 'autonomy' has been used to refer to at least five different modes of learning (see Benson and Voller, 1997, p. 2):

- for situations in which learners study entirely on their own;

- for a set of skills which can be learned and applied in self-directed learning;

- for an inborn capacity which is suppressed by institutional education;

- for the exercise of learners' responsibility for their own learning;

- for the right of learners to determine the direction of their own learning.

There have also been other attempts to explain the concept and what it entails (Benson, 2007; Benson and Voller, 1997; Ho and Crookall, 1995; Little, 1990; Schmenk, 2005). Little (1990), for example, has tried to demystify some of the ambiguities that became prevalent over the years. For example, he argues that learner autonomy is not a teaching method or a single learner behaviour that can be easily described. He adds that autonomy cannot be equated to selflearning. He defines learner autonomy as "essentially a matter of the learner's psychological relation to the process and content of learning - a capacity for detachment, critical reflection, decision-making, and independent action" (Little, 1991, p. 4). Nunan (1997) and Thanasoulas (2000) contend that autonomy is not an absolute trait as it can take different forms depending on various factors, such as age, learning experience, learning goals and perceptions about learning. These misconceptions continue to exist despite the large amount of research on the subject.

Other researchers have stressed the role of the cultural and ideological context where learning and teaching take place in the development of LA (e.g. Dam, 1995; Palfreyman, 2003; Smith, 2003). It is believed that there are certain factors that can affect the degree of autonomy one could have. These factors include societal expectations, personal perceptions, etc. According to Dam (1995), learners will not become autonomous learners unless they have the willingness to take responsibility. Benson and Winnie (1998) report on a study that investigated learners' views about LA. They analyzed learners' beliefs from four perspectives, socio-cultural, technical, psychological, and political perspectives (see also Benson, 1997). The technical views are concerned with the physical setting in the learning environment, while the socio-cultural conceptions are related to the social interactions and relationships that are inherent in the society. The psychological perspectives refer to the intellectual readiness that learners possess. The presence or absence of these views can support or hinder the development of LA. Benson and Winnie (1998, p. 57) conclude that:

... learning behaviors are conditioned by overarching conceptions of the object and process of learning ... If learners broadly adopt the view that languages consist of things to be learned and approach the task of learning as the accumulation of those things, they are less likely to respond positively to autonomy. If they adopt the view that language is an unfamiliar environment with which they must come to terms and approach the task of learning as one of exposure, understanding and personal adaptation, they are more likely to respond positively to autonomy.

Learner autonomy has now become an important part of language education. It is seen as a way of empowering students to take responsibility for their own learning inside and outside the classroom environment. Language programmes either integrate autonomy training into other skill courses or in a separate course. Several principles for integrating learner autonomy into the curriculum have been proposed (Cotterall, 2000; Little, 2001; Little, 2007; Little, 2009). These include:

- Learner involvement - in setting goals, learning activities, etc.

- Learner reflection - on learning process and achievement

- Target language use - communicative and meaningful language use

- Strategy training.

In this paper, we argue that for an effective integration of LA into the language curriculum, teachers' views must be taken into consideration. Palfreyman (2003) notes the gap between the theoretical definition of LA and the teachers' understanding of the concept. Teachers' views about LA are shaped by the different ways of conceptualizing LA. Teachers' beliefs about LA are equally important. They do not only dictate how teachers perceive of LA but they also shape the teachers' practices. The present study has attempted to shed light into the teachers' conceptions about the concept of LA and sources where these are drawn. 


\section{B. Teachers' Beliefs about Learner Autonomy}

Despite attempts towards consideration of the role, perceptions and practices of both learners and teachers with regard to the concept of autonomy (Lamb, 2008), there is still little research addressing the concept of learner autonomy from the perspective of the English language teacher.

A current survey of the literature on teachers' perspectives on learner autonomy yielded only a handful of studies (Chan, 2003; Balçıkanlı, 2010; Al Asmari, 2013; Borg and Al-Busaidi, 2012a and 2012b). Chan (2003) conducted a large scale mixed-method study which investigated 41 English teachers' perspectives of their roles and responsibilities about leaner autonomy and their assessment of their learners' ability to undertake decisions about learning in an institute in Hong Kong. The study concluded that the teachers thought themselves to be responsible for the methodological decisions (setting objectives and designing assessments) and less responsible about both the students' engagement in activities and their progress in learning English out of class.

Balçıkanlı (2010) conducted a study to explore 112 student teachers' beliefs about learner autonomy in a Turkish university using a survey. Additionally, a total of 20 interviews were conducted to assess these student teachers' overall attitudes towards learner autonomy. The findings suggest that the teachers had positive attitudes towards learner autonomy. However, although the student teachers agreed to the involvement of their learners in most of the areas of teaching and learning, most expressed reservations about involving their students in the decision-making process regarding the time and place of the course and the textbooks.

Al Asmari (2013) investigated 60 EFL teachers' notions, practices and prospects of learner autonomy in a language centre at a Saudi university using a questionnaire. It was found out that the teachers held low assessment of the learners' ability towards learner autonomy. With regards to strategies to promote learner autonomy, the teachers favored the strategies of teaching communicative skills, organizing group discussions, and adopting a learner-centered approach. The teachers further viewed continuous professional development, reflection on the teaching-learning process and learner learning as steps to improve the current situation on learner autonomy.

Borg and Al-Busaidi (2012a) explored 61 teachers' beliefs and practices of learner autonomy in one language centre at a university in Oman using a questionnaire. The findings suggest that in theory the teachers held favorable views about the importance of learner autonomy to second language learning. In practice, however, the teachers were less confident about their learners' possession of autonomy. Further, though the teachers were positive about the desirability of promoting learner autonomy, they were less positive about the feasibility of inculcating learner autonomy in the students. The researchers identified learner factors (e.g., inadequate levels of motivation), teacher factors (e.g., low expectations towards learners) and institutional factors (e.g., curriculum overload) as possible hindrances against promoting learner autonomy in the English classrooms in the setting. The present study is part of an earlier larger study reported in Borg and Al-Busaidi (2012a and 2012b), and reports on findings from the interviews that were conducted as part of the earlier study.

The current study aims to explore experienced ELT teachers' beliefs about learner autonomy. Researching the notion of teacher belief is not problem-free. In contrast to teacher knowledge in the area of teacher cognition, research on teachers' beliefs received very little attention (Borg, 2006). In educational research, Pajares' (1992) work is the only review available of teachers' beliefs. Recognizing that the construct is "diffuse and ungainly, too difficult to operationalize, [and] too context free" (p. 316), Pajares (1992) suggests that researchers utilize 'beliefs about' as one way to provide conceptual clarity. Some researchers (e.g. Verloop et al, 2001), however, see no need for differentiating knowledge from beliefs because according to them "in the mind of the teacher, components of knowledge, beliefs, conceptions and intuitions are inextricably intertwined" (p. 446). There is also no consensus on the meaning of beliefs (Borg, 2001), and some scholars prefer to use an all-encompassing term such as teacher cognition (Borg, 2003), and BAK or beliefs, assumptions and knowledge (Woods, 1996).

Given the centrality of beliefs in teachers' professional life as potentially affecting beliefs about and practice in teaching, a point well-established in mainstream and language education cognition research (Borg, 2001, 2006; Pajares, 1992), this study works on a conceptualization of teacher belief about learner autonomy which is grounded in the following parameters: teacher concepts of learner autonomy, and the origins of these concepts.

\section{RESEARCH METHODOLOGY}

The study aimed to address two research questions:

1. How do teachers define learner autonomy?

2. What are the sources of the teachers' definitions?

\section{A. Participants}

This study took place at the Language Centre (LC) at Sultan Qaboos University (SQU) in Oman. The sample was drawn from a population of more than 200 teachers of over 30 nationalities who teach English to around 3500 Omani students preparing for undergraduate study at the University. This study aimed at investigating the teachers' beliefs about learner autonomy.

The sample was drawn from a larger study that investigated the teachers' beliefs about learner autonomy (for more information about the study see Borg and Al-Busaidi, 2012a and 2012b). In that study, the participants were given a 
questionnaire about the concept of learner autonomy and were asked if they would be interested to participate in follow up, individual interviews. The purpose of the interviews was to further explore the teachers' answers to the questionnaire questions and to elicit specific examples from teachers about their responses to some of the issues in the study. Out of the 61 teachers who answered the questionnaire, 42 teachers volunteered to do a follow up interview. However, given time constraints, the researchers were only able to interview 20 teachers. The interviews lasted an average of 30 minutes each. The 20 teachers were chosen using criteria from two specific responses to the questionnaire questions, namely (a) teachers' beliefs about how autonomous their students were and (b) teachers' years of experience in ELT. There were more than 20 teachers who met these criteria. Borg and Al-Busaidi (2012a, p. 285) describe how the interviewees were selected:

Interviewees were chosen using stratified random sampling (see Bryman 2008). In a stratified sample the criteria for selection are represented in the same proportions as they are in the larger group the sample comes from. This makes the sample more representative of the larger group. Thus, for example, in the larger sample of teachers in the study, 30 teachers (just under 50 per cent) had four years' or less experience in ELT; in the sample of 20 interviewees, there were ten teachers ( 50 per cent) with this range of experience.

\section{B. Instrument}

Semi-structured interviews were chosen for the purpose of allowing an element of flexibility. The researchers developed a common framework for the interviews but it was then adapted to suit each interviewee and their responses to the questionnaire. The interviews used the teachers' individual responses to the questionnaire as prompts for the interviews. The interviewees were 18 female teachers and 2 male teachers with different years of experience. Seven were native speakers and thirteen non-native speakers of English. The researchers did not control for the gender or native-speaker aspects because these were not deemed important in the original study.

The interviews were conducted over a period of one month. Ten interviews were conducted face to face in Oman and the other ten by phone from the UK. All interviews were conducted in English and were audio recorded with permission from the interviewees. The fact that some of the interviews were conducted face to face while others on the phone had probably affected the nature of the interaction that took place, the former allowing for opportunities to use stimulus material or body language for explanation and clarification or making the interviews less formal (Borg and Al-Busaidi, 2012b). Still, because the interviews were based on participants' responses to the original questionnaire, the abstractness of the discussion was reduced by focusing participants' attention to their concrete responses (Kvale, 1996). The researchers in the original study followed the institutional ethical procedures at the University of Leeds in conducting the interviews. The participants were given information about the study and were asked if they were interested in it. Confidentiality was ensured throughout the study. The researchers used codes to refer to the interviewees in order to protect the interviewee's identity. Additionally, the results were reported back to the participants through professional development workshops and publications.

\section{Data Analysis}

The analysis of the interview data of the Language Centre teachers was carried out on NVivo 9. This is ComputerAssisted Qualitative Data Analysis Software (CAQDAS) with facilities to aid in the analysis of qualitative data. Different techniques were employed on the data. The analysis was done in reference to the research questions (Janesick, 1994, p. 210), and the overall approach to analysis was inductive in the sense that the extant theoretical literature on learner autonomy did not inform the analysis at this early stage. This was facilitated by the data analyst not being involved in the data collection in the earlier studies (See Borg and Al-Busaidi, 2012a, 2012b) in the sense that the analysis was grounded into the data of the interviews rather than being directed by and emerged from the findings of the first study. This gave the analyst a different frame of mind from that which has guided the earlier study.

The whole process, described below in full detail, went through three major phases. First, data was analyzed using NVivo 9. Secondly, the procedures and the direction of the analysis, as well as the meanings emergent of the data were discussed and refined. Thirdly, the researchers wrote holistic analytical constructions of the emergent insights obtained from the data based on the posed research questions. Only in the final stages was the theoretical framework (Holliday, 2002) of learner autonomy allowed to shed light on the emergent analysis.

The analysis in the initial stage involved coding the data under different nodes (i.e. meaning containers) that were simple and descriptive. This process of coding was the lengthiest of the processes, which culminated in writing around 200 nodes on all interview data. The researchers went over the data numerous times in order to establish meanings. Afterwards, the individual nodes were organized into tree nodes, based on the overarching meaningful category they belonged to. For example, meanings about teachers' learning experiences were coded under 'language learning', and those relating to the education of these teachers' children coded under 'parenting'. Both of these categories were coded under 'Sources', and so forth. At that stage, the data under each node were read once again, and their relevance to the tree nodes was further assessed through constant comparison (Miles and Huberman, 1994). This was facilitated by Strauss's and Corbin's axial coding (1990), studying contextual and meaningful clues, to provide more refined crosstabulations. This process led to some nodes being transferred to different categories or further nodes refined to conform to the meanings of the tree nodes. This pertained to the points made below about whether some meanings needed to be coded under one category or another, for example 'professional development or 'initial teacher education'. With the 
consensus reached about the meanings of these two concepts, codes were placed accordingly. These categories were then organized according to the research questions of the study.

The credibility of the data analysis was assured through multiple discussions of the coding and categorization of the data. Issues relating to the meanings of the categories were agreed upon. For example, differences between 'professional development' and 'initial teacher education' were discussed. It was decided for example that for this research the meaning of 'initial teacher education' signifies first qualifications earned to obtain a job as an English language teacher. The concept of 'professional development' was made more precise using 'in-service professional development' which indicates more subsequent and on the job training or education which the teacher has received (e.g., attending a workshop, a conference session, doing another degree such as an MA or a $\mathrm{PhD}$ degree). Further, following Lincoln and Guba (1985), an audit trail process was achieved throughout the process of analysis through the researcher recording insights on the process and meanings of the emerging data.

\section{RESUlts}

The results are organized by the research questions, with the aim to provide thicker and more in-depth insights about the issues addressed in the earlier studies (Borg and Al-Busaidi, 2012a and 2012b).

\section{A. Teachers' Understanding of Learner Autonomy}

The analysis which was based on the earlier studies (Borg and Al-Busaidi, 2012a and 2012b) relating to the conceptions of LA focused on the broad and metacognitive aspects, and presented a majority view (Borg and AlBusaidi, 2012a). In this study, in addition to the metacognitive ones more fine-tuned nuances of definitions are present such as definitions focused on pragmatic issues and dualist conceptions.

Pragmatic conceptions are these which are focused on issues which directly deal with the teachers' day-to-day teaching matters related to curriculum, materials, teaching methodology, or learning strategies. One teacher combines all:

Q: How would you define an autonomous learner?

A: That the learner would feel empowered to decide on the objectives after a certain amount of education, because learners at different ages would be less informed about objectives and how to achieve them. And once they're educated, once they're enlightened, ... then they have every freedom, ability to input into objectives, into assessment forms, into methodology, material, whatever, that they were completely involved in it. (EN)

On the broad dimension of LA definitions, the teachers focused on defining learner autonomy from a metacognitive angle. These definitions are not about learning per se, but relate to conceptions that are about learning, strategies that regulate this learning. This orientation reminds one with the definitions which abound in the earlier literature on learner autonomy. Conceptions about 'independence', 'freedom', 'voice', 'decision', 'choice', 'control', 'charge', and 'responsibility' have dominated the definitions of this kind (See Little, 1991). One example is the following:

I equate it with the idea that the student should have choice or that a learner, a learner should have choice and some kind of control over their own learning, that, something like that (AG)

Learner autonomy to me means giving independence to students, to learners (AM)

But basically [LA] is just trying to help students take charge of their own learning, as much as possible. (JA)

Therefore, in the above quotes notions of 'taking charge', 'independence', 'control' and 'choice' resonate with metacognitive ideas, which are reminiscent of strategies used to regulate and self-direct learning.

The dualist conception of LA by the teachers proved to be especially interesting. This dualist conception indicates a very complex network of thinking on the part of these very experienced EFL teachers in combining concepts that depict the versatile facets of the concept of learner autonomy in a few words. Whilst the teachers defined LA using the classic combinations of autonomy and control/instruction or freedom or guidance as in the earlier pragmatic and metacognitive definitions, there are definitions which combined some unusual characteristics of learner autonomy. For example, learner autonomy is seen to encompass both content and process, process and the result, and responsibility and right. One teacher emphasizes that teachers in class can oversee both content and the process for planning the content:

Well not all teachers realise that actually teachers can exert autonomy in content even, classroom teaching content. In the event that teachers actually cannot have control over, well their preferred topic or preferred content, subject content that they want to teach specifically or get them to talk about. They could actually have control over process. So this way we would actually invite the conversation so that learners can bring their scheme ... out of the class and they will actually participate in constructing knowledge. (MS)

Another teacher differentiates between autonomy as process in the opportunities that are being created for/by the learner to develop their English, and autonomy as product, in the attribute which the successful learner ends having:

When it comes to my profession, autonomy, when it comes to ESL, when it comes to language learning, is when you have two ways communication, you have to train a person to be an autonomous learner, that means do the same you can as a learner of English of a more advanced level, and also to provide an opportunity for learning, so it's the process and the result, that's the way I see that in the ESL context. (GM) 
A third teacher stresses that an autonomous learner is not only responsible for assuming responsibility of their own learning and its pace, but also possesses the right to be given this opportunity and to be made aware of its potential and benefit to language learning or learning in general for that matter:

learner autonomy means that the learner has full responsibility and right to choose what to learn how to learn and when to learn, and to be able to assess (GB).

In sum, because of their broad quantitative nature, the earlier studies (Borg and Al-Busaidi, 2012a and 2012b) offered one monolithic definition which "involved learners in having the freedom and/or ability to make choices and decisions" (Borg and Al-Busaidi, 2012a, p. 286). This study, by contrast, as was clearly highlighted above, provided the teachers' understandings of learner autonomy, with its rich and versatile facets.

\section{B. Sources of the Teachers' Views of Learner Autonomy}

The data suggest that the origins of the teachers' cognitions regarding learner autonomy, LA, came from three major sources: language teaching, language learning, and professional development, and a combination of all of these.

\section{Language teaching}

When the teachers talked about the sources of their cognitions of learner autonomy with regard to teaching, they talked about their formal as well as their experiential (related to classroom experience) components. The formal component focused on training through first degrees (also MA level, and PhD level) in teacher training institutions. Below we show a narrative from a teacher talking about an MA program 35 years ago where she/he points out that though the clothing of LA is new, its core meaning has been in ESL for quite a while:

I have a Masters in education, intercultural education with an ESL specialty, and that was in 1975 and 1976 . And we were, I think the terminology is a bit different but a lot of the ideas are the same. So we were studying teaching methodology such as the open classroom, I don't know if you've ever heard of that.

I've heard of it.

A Montessori School methodology where students work independently in the classroom with the guidance of the teacher, doing their own projects and pursuing their own interests. So, some of the ideas that I think I've had exposure to in the 1990 s, maybe since the 1990 s when the paradigm shift, I really feel like, in higher education, the paradigm shift from the teacher centred classroom to the learner centred classroom was occurring. But some of those ideas are, of course, not new ... (BV)

The experiential component, this appearing to far less extent compared to training, is related to the teachers' classroom teaching experience through observation of their students, and through promotion of autonomy amongst their students, as one teacher demonstrates:

I guess it [the source of my views on LA] comes out of experience through teaching and personal experience myself. I think one of the things I try to promote with students and try to demonstrate as an example to them is lifelong learning, and I strongly believe that we need to be lifelong learners, and that being a lifelong learner can help you in so many ways as an individual, and in terms of your career, in terms of personal goals you want to meet and so on. So, again, from seeing those students that are more successful, and for understanding why I may be successful in learning some subjects versus others, I think that having that autonomy is an important part of that equation. (DS)

Upon reflecting on her students in her classroom, the teacher in the above extract demonstrates the relationship between autonomy and success in learning a foreign language, and particularly sees that successful students are autonomous learners.

\section{Language learning}

The data in this category relate to two dimensions of language learning: the teachers' experiences as language learners, and their experiences as parents (parenting). These experiences ranged from reflecting on purpose for learning English which was not for instrumental purposes, reflecting on the pace and learning techniques used, reflecting on the opportunities outside the class, i.e. activities engaged in outside the language classroom (e.g., watching t.v, reading books, etc.), strangely but reflecting on their schooling experiences which were strict structured and teacher oriented, engaging in a learning situation to reflect on their learning, so that they are on equal planes with the learners, and taking charge of school societies outside the classroom. When describing their experiences as language learners, these teachers talked about the versatile facets which LA showed them. This runs contrary to the apprenticeship of observation which states that the potential teachers make note of teachers' actions, strategies and skills during their schooling years to accumulate knowledge about ELT.

It is very interesting to note that the polarized school structure as strict, on the one hand, and as lenient, on the other, had an influence on these teachers' thinking regarding LA, as this quote shows:

Q: Now how have you come to develop these views about autonomy, is it because of that book that you read about the school?

A: I'm sure that that was the start, Summerhill, and then myself being, going to parochial schools with very, very strict structure (TGL)

Coming from a teacher-centred system, another teacher described the influence of schooling experience as follows:

Q: How did you form these views about learner autonomy, and was it, for example, based on your teacher training, or maybe based on your experience, or other factors? 
A: Like I told you, if I, I just yesterday, with trying to think about the topic, and I was thinking of my experience as, as a learner, as a student. Like I told you, I am from very teacher oriented system, and I can't say that I got much training in learning how to learn things. That's why, right now, again, I read a lot about this topic, and I try to use some things in my classroom on an, on every day basis, for example, I like very much mind mapping. I think it's a very, very useful skill for students, for different purposes, whether it's for writing, for planning their writing, or for reading, the ability to see the structure of the text, and to be able to transfer the information from one mode to another, or for planning things, or for presentations, or whatever. That's why I try to use elements of it in different, in different aspects (GB).

On the parenting issue as one source of the teachers' cognitions on learner autonomy, the teachers talked about how they were involved in the education of their kids in issues related to type of schools and type of courses. Here is one example:

[For my kid] it didn't matter what the teacher said or what I said or what anything, or the grade he got, he could take, in high, secondary school he could take Advanced Placement History from Dr Wilkerson and get an A and he would, because of the system he was, he must take Art or Music or some Fine Arts, he would fail. How can you fail Art ...? Well it was boring (TGL).

Another teacher approached the influence of parenting from an entirely different perspective, one which is different from the earlier quote:

Q: Yes, and you said your own experience as a learner, or as a language learner, had an influence on how you feel about autonomy. Could you tell me a little bit more about that?

A: Yes, because the thing is, well, I mean I've always thought of myself as an independent person, and I think it always to me, the birth order makes the role, because I'm the oldest of my brothers and sisters, and because of that I've always, like, I mean the family, my parents have always depended on me to take care of my brothers and sisters, so I grew up with like responsibilities, I mean, I'm supposed to help them out, like sometimes help them, feed them, take care of them, stay with them, babysitting, so that had an influence on me as a learner, and I've always been interested in learning language, I mean English as a language, it has nothing to do with wanting a job, I never really thought of myself becoming an English teacher. It was always that I was interested in English, and I think because of the birth [order] (NK).

Whilst the above two extracts are common in revealing the influence of parenting on the teachers' views on learner autonomy, they illustrate two approaches in conceptualizing the role of parents. The first teacher was reflecting about his son schooling experience as a father, and the second came from a teacher who was reflecting on the responsibility given to her by her parents to take care of her brothers/sisters. This made this teacher relate her autonomy as a foreign language learner to her parents' method of rearing her.

\section{In-service professional development}

In the area of professional development as a source for the teachers' cognitions on learner autonomy, the data suggest that the teachers have their ideas about learner autonomy from attending conferences and workshops, readings in the literature that define learner autonomy or report on its implementation in different learning contexts. References to the literature included the following:

- Holec's definition of LA

- David Little's work and then also the English language portfolio

- Ellis and Sinclair's Learning to Learn, the actual course book

One example extract is the following:

As I said before I would really like to follow Holec's definition which I have adapted actually, learner autonomy to me is the capacity to take control over learning which would come in the form of different levels, different forms according to the uniqueness, the individuality of learners. It's an attribute, it's a mode of learning and teaching and teaching material should foster autonomy. Because the other side of the coin is teacher autonomy where teachers cannot have control over content, teachers need to focus on the process of teaching so that you can foster actually autonomy in the classrooms. (MS)

Another teacher explains how at his first teaching assignment in Oman, he has been reading about LA from an early book on this theme at the time:

Q: Has there been anything in your teacher training, teacher development where autonomy has been a particular focus and that may have shaped your views?

A: Training not so much but development in the sense of attending conferences, listening to speakers, reading different articles. I remember way back when I first came to Oman actually picking up Ellis and Sinclair's Learning to Learn, the actual course book (AG)

A third teacher is this teacher who has learned a great deal about learner autonomy, and still does, from both the Master's degree she did, and from the doctoral research that she is currently doing:

Q: How have you come to develop these views? Was it for example through your teacher training? Or from experience in the classroom? Or something else?

A: When I answered this questionnaire it was actually based on my teacher experience, when I was doing masters we just basically touched on the topic and now that I have started the PhD I'm focusing more. And actually after answering 
the questionnaire I focused more on learner autonomy and started reading and it made me realise actually my beliefs are in par with the other's ideas in the field, so it got me really interested. (MS)

A fourth teacher has gathered information on learner autonomy from a collaborative project on self-assessment with a colleague of her. She explains as follows

Q: Now how have you come to develop these views about learner autonomy? Did you, for example, did you in teacher training or experience?

A: Sure. Actually in 2007 a colleague and I were doing a presentation on using self assessment in the classroom and we drew upon the David Little's work and then also the English language portfolio that was used there. And so for the writing class that I had and the speaking listening class that she had we were trying to see if we could use self assessment with the students as a means of alternative assessment ... (MY)

Despite these clear-cut categorizations of the influences, in some instances, it was difficult for the teachers to attribute these influences to one source. This is understandable since the teachers interviewed were very experienced EFL teachers, as was explained earlier, and have accumulated experience and understanding from a wide range of sources. However, there were a few teachers who identified a combination of sources that were responsible for their understanding of LA. The following teacher has developed her views as a learner and then subsequently as a teacher:

Q: Now, how did you develop these views about learning autonomy? Was it, for example, through training that you had when you were doing your degrees, or your experience?

A: Definitely, when I was a language learner I was aware that it will not be enough to stop learning something in the classroom, I'll have to take back some things home and continue ... So I think I became aware as a student and, when I started teaching, I could see a significant difference between responsible students who've completed tasks given, who did more learning on their own and were more motivated and took responsibility, do better. So I saw that autonomy made a difference to performance. (AS)

Another teacher combined formal training, teaching and experience in learning French:

Q: How do you think you've come to develop the views that you hold today about learner autonomy?

A: I wouldn't say my training but until you're teaching yourself or learning yourself, then you really do understand, because, first of all, as a language learner, my first Degree is in Languages, so I learned two foreign languages to a high level and on reflecting. And in one of those languages in particular, I was autonomous, to a certain degree, ... I don't know what it's like today, but Secondary School wouldn't really have encouraged autonomy in foreign language learning, we didn't have any language labs, or computers, and there was no internet or anything, ... but I did a lot of extensive reading, say, in French, it helped by a sister who lived in a French speaking country and who would bring me material, ... And that was about myself, and that's why I hold such strong views and such positive views about autonomy. (CN)

Here is how a third teacher linked several different influential sources (i.e. schooling experience, initial training, professional development) for her ideas on learner autonomy:

Q: Have there been particular influences in your life, in your education, in your professional work, which have influenced how you feel today about learner autonomy?

A: I think with me, maybe I've been lucky starting from school I've been involved in so many societies apart from classroom activities, and I took charge of some societies. And then when I went to university, we were doing, I did Languages basically, and we were taught by different people from different backgrounds and mostly from the West, and you're just exposed to different schools and different experiences. I think this has contributed to shape my experience. Plus I've done my MA in Australia and you tend to look critically at what could work for your context and what could work for your students when you come back for a classroom and how you can make use of whatever available resources you've got. And it doesn't stop, actually that's why it's like, it's connected more with professional development, you look at things, you see how they could fit into your context, so it's, basically it's something that is constant with me, constantly going on. (JA)

\section{DISCUSSION}

This qualitative study has investigated learner autonomy from the perspectives of EFL practitioners. The study specifically explores the teachers' understanding of learner autonomy and the sources of their understanding.

There are certain points that can be drawn in the discussion that are pertinent to the findings of the study. First, a group of teachers defined what the concept of learner autonomy meant to them by relating it to their daily practices including teaching methodology and assessment and materials' development. A few also defined LA in relation to what is most common in the literature of learner autonomy with regard to control, capacity and freedom. A third group defined autonomy emphasizing its seemingly contrasting qualities such as process and product, process and content, and right and duty. These various conceptions of learner autonomy can be related to the teachers' varied and long experiences.

Though some of these issues have been dealt with in Borg and Al Busaidi (2012a, 2012b), the distinctiveness of this study is in the deeper analysis and interpretation of the teachers' understanding. For example, LA conceptions can be related to the sources of the teachers' ideas on learner autonomy. A group of teachers formed their ideas on LA from teacher education/training programmes and their classroom practice (i.e. the pragmatic definitions). Another group of 
teachers talked about their experiences in language learning as sources of their concepts of LA. There are two points of interest with regard to the sources of these ideas. The first point is that the teachers not only referred to their language learning experiences as learners of L2 themselves, but also as parents in relation to their children's learning experiences. The second point is that contrary to the apprenticeship of observation (Lortie, 1975), these teachers never referred to the sources of their ideas on LA as stemming from watching and observing their teachers' teaching practices in the English classroom. One reason which may explain this absence of connection is the wide teaching experience that these teachers have accumulated. A third group of teachers said that they knew the information about LA from their in-service development programmes such as reading for research and attending conferences and doing presentations. Professional development opportunities seem to have long lasting impact on teachers.

The findings of the study support those of previous studies about the high regard teachers hold for the development of LA. The study has also indicated that teachers from different backgrounds vary in their understanding of LA. The teachers' understanding is influenced by personal, educational and pragmatic factors. There are many ways to further promote LA among students and teachers. Understanding the perceptions that students and teachers have about this important concept is a crucial step towards the development of leaner autonomy.

\section{CONCLUSION}

The present study sought to explore the teachers' perceptions about learner autonomy. It specifically examined the teachers' definitions of LA and the origins of their views. The study revealed the complexity of teachers' cognitions in describing LA. It showed that teachers hold different views about LA. These views are governed by factors such as the teachers' backgrounds, education, and experience. Future research can focus on the effect teachers' views might have on their classroom practices.

There are still many unsettled issues, such as the learner and teacher roles, the nature of materials required, the type of teacher preparation needed, and the best ways to assess students' attainment of such a trait. We hope that our study has shed some light into some of these aspects of LA that remain under-studied from the teachers' perspectives.

In conclusion, we believe that in order for teachers to promote LA they themselves should have a degree of autonomy in managing their courses. Non-autonomous teachers should also be provided with training on how to be autonomous. Teacher education programs need to provide opportunities and training for their student teachers on how to promote LA in their teaching.

\section{ACKNOWLEDGEMENT}

The authors wish to thank Professor Simon Borg for his feedback and advice on earlier versions of the paper. The data for this work came from a research project that was funded by grant from the British Council.

\section{REFERENCES}

[1] Al Asmari, A. (2013). Practices and prospects of learner autonomy: Teachers' perceptions. English Language Teaching 6.3, 110.

[2] Balçıkanl, C. (2010). Learner autonomy in language learning: Student teachers' beliefs. Australian Journal of Teacher Education 35.1, 90 - 103.

[3] Beson, P. \& L. Winnie. (1998). Making sense of autonomous language learning. English Centre Monograph No. 2. (ED 428570). Hong Kong: Hong Kong University, English Language Centre.

[4] Benson, P. (2007). Autonomy and its role in learning. In J. Cummins \& C. Davison (eds.), International handbook of English language teaching part 1. US: Springer, $733-745$.

[5] Benson, P. (2006). Autonomy in language teaching and learning. Language Teaching 40.1, 21-40.

[6] Benson, P. (1997). The philosophy and politics of learner autonomy. In P. Benson \& P. Voller (eds.), Autonomy and independence in language learning. London: Longman, 18 - 34.

[7] Benson, P., \&Voller, P. (eds.). (1997). Autonomy and independence in language learning. London: Longman.

[8] Borg, M. (2001). Teachers' beliefs. ELT journal 55.2, 186-188.

[9] Borg, S. (2006). Teacher cognition and language education: Research and practice. Continuum: London.

[10] Borg, S, \& S. Al-Busaidi. (2012a). Teachers' beliefs and practices regarding learner autonomy. ELT Journal 66. 3,283 - 292.

[11] Borg, S. \& S. Al-Busaidi. (2012b). Learner autonomy: English language teachers' beliefs and practices. Reported submitted to the British Council, UK. (Published report). Available at: http://www.teachingenglish.org.uk/publications. Retrieved on October 15, 2014.

[12] Bryman, A. (2008). Social research methods (3rd edn.). Oxford: Oxford University Press.

[13] Clark, C.M., \& Peterson, P.L. (1986). Teachers' thought process. In M.C. Wittrock (ed.), Handbook of research on teaching. New York: Macmillan, 255-296.

[14] Chan, V. (2003). Autonomous language learning: The teachers' perspectives. Teaching in Higher Education 8.1, $33-54$. doi:10.1080/1356251032000052311.

[15] Cotterall, S. (2000). Promoting learner autonomy through the curriculum: Principles for designing language courses. ELT Journal 54.2, 109-117.

[16] Dam, L. (2008). In-service teacher education for learner autonomy. Independence 43 (IATEFL Learner Autonomy SIG), Summer 2008, 20 - 26.

[17] Dam, L. (1995). From theory to classroom practice. Dublin: Authentik. 
[18] Hegde A. V., \& D. J. Cassidy. (2009). Teachers' beliefs and practices regarding developmentally appropriate practices: a study conducted in India. Early Child Development and Care 179.7, 837-847.

[19] Holec, H. (1981). Autonomy and foreign language learning. Oxford: Pergamon. (first published in 1979, Strasbourg: Council of Europe).

[20] Ho, J. \& D. Crookall. (1995). Breaking with Chinese cultural traditions: Learner autonomy in English language teaching. System 23.2, $235-243$.

[21] Holliday, A. (2002). Doing and writing qualitative research. London: Sage.

[22] Isenberg, J. P. (1990). Teachers' thinking and beliefs and classroom practice. Childhood Education 66, 322-327.

[23] Janesick, V. J. (1994). The dance of qualitative research design: Metaphor, methodolatry, and meaning. In N.K. Denzin \& Y.S. Lincoln (eds.), Handbook of qualitative research. Thousand Oaks, CA: Sage Publications, 209-219.

[24] Kvale, S. (1996). InterViews: An introduction to qualitative research interviewing. Thousand Oaks, CA: Sage.

[25] Lamb, T.E. (2008). Learner and teacher autonomy: synthesizing an agenda. In Lamb, T.E. and H. Reinders (eds.), Learner and teacher autonomy: Concepts, realities and responses. Amsterdam: John Benjamin.

[26] Lincoln, Y. S., \& E. G. Guba. (1985). Naturalistic inquiry. Beverly Hills, CA: Sage.

[27] Little, D. (1991). Learner Autonomy 1: Definitions, issues and problems. Dublin: Authentik.

[28] Little, D. (1990). Autonomy in language learning. In I. Gathercole (ed.), Autonomy in language learning. London: CILT, 7-15.

[29] Little, D. (2001). We are all together: exploring the interdependence of teacher and learner autonomy. In L. Karlsson, F. Kjisik \& J. Nordlund. (eds.), All Together Now. Helsinki: University of Helsinki, Language Centre, 45 - 56.

[30] Little, D. (2007). Language learner autonomy: Some fundamental considerations revisited. Innovation in Language Learning and Teaching 1.1, $14-29$.

[31] Little, D. (2009). Language learner autonomy and the European language portfolio: two L2 English examples. Language Teaching 42.2, $222-233$

[32] Lortie, D. (1975). Schoolteacher: A sociological study. London: University of Chicago Press.

[33] Miles, M. B., \& A. M. Huberman (1994). Qualitative data analysis: An expanded sourcebook (2nd ed.). Sage publications: Thousand Oaks.

[34] Nunan, D. (1997). Designing and adapting materials to encourage learner autonomy. In P. Benson \& P. Voller (eds.), Autonomy and independence in language learning. London: Longman, 192-203.

[35] Pajares, M. F. (1992). Teachers' beliefs and educational research: Cleaning up a messy construct. Review of Educational Research 62.3, 307-32.

[36] Palfreyman, D. (2003). Introduction: culture and learner autonomy. In D. Palfreyman \& R. Smith (eds.), Learner autonomy across cultures: Language education perspectives. London: Palgrave Macmillan, 1-19.

[37] Schmenk, B. (2005). Globalizing learner autonomy. TESOL Quarterly 39.1, 107 - 118.

[38] Smith, R. (2003). Pedagogy for autonomy as (becoming-) appropriate methodology. In D. Palfreyman \& R. Smith (eds.), Learner autonomy across cultures: Language education perspectives. London: Palgrave Macmillan, 129 - 146.

[39] Strauss, A. \& Corbin, J. (1990). Basics of qualitative research: Grounded theory procedures and techniques. London: Sage.

[40] Thanasoulas, D. (2000). What is learner autonomy and how can it be fostered? The Internet TESL Journal 11. Website: http://itesl.org/Articles/Thanasoulas-Autonomy.html. Retrieved on: 5/13/2009.

[41] Verloop, N., J. Van Driel \& P. C. Meijer. (2001). Teacher knowledge and the knowledge base of teaching. International Journal of Educational Research 35.5, 441-61.

[42] Woods, D. (1996). Teacher cognition in language teaching. Cambridge: Cambridge University Press.

Saleh S. Al-Busaidi is an assistant professor of English as a foreign language at Sultan Qaboos University, Oman. He is currently the director of the Language Centre. He received his BA in TEFL at Sultan Qaboos University in 1995, his MA in TEFL at the University of Exeter, UK in 1997, and his $\mathrm{PhD}$ in Curriculum Studies at the University of Illinois at Urbana-Champaign, USA in 2003. Dr Al-Busaidi has also participated in many national and international conferences and symposia. He has also published journal articles and book chapters on areas related to English language teaching and learning. His main research interests are: material development, study/academic skills, academic readiness and difficulties and language acquisition.

Faisal S. Al-Maamari earned a Bachelor of Education in TEFL (1999), Sultan Qaboos University, Oman, a Masters' of Arts in ELT (2001), University of Warwick, The United Kingdom, and PhD (2011), University of Bristol, The United Kingdom. He is currently an Assistant Lecturer at the Language Center at Sultan Qaboos University, Sultanate of Oman. He has been teaching EAP English since 1999. Dr. Al-Maamari's main research interests are in programme identity, organizational change, teacher education and research methodology. 